\title{
The Nature of Truth: Investigation of Logic and Belief
}

\author{
Yakub Nasucha ${ }^{1}$, Harun Joko Prayitno ${ }^{2}$, Miftakhul Huda ${ }^{3}$, Ku-Ares Tuwandorloh ${ }^{4}$, Yunus Sulistyono ${ }^{5}$, \\ Awla Akbar Ilma ${ }^{6}$, Teuku Afrizal ${ }^{7}$ \\ \{yn254@ums.ac.id ${ }^{1}, \underline{\text { hip220@ums.ac.id }}{ }^{2}$, mh130@ums.ac.id $^{3}$, kumukhlish-tel@hotmail.com $^{4}$, \\ ys122@ums.ac.id ${ }^{5}$,awlaakbar24@gmail.com ${ }^{6}$, teukurian@yahoo.com ${ }^{7}$ \\ \}
}

Universitas Muhammadiyah Surakarta, Indonesia ${ }^{1,2,3}$, Fathoni Universitsy, Thailand ${ }^{4}$, Leiden University, The Netherland ${ }^{5}$, Suez Canal University, Egypt ${ }^{6}$, University Malaysia Sabah, Malaysia ${ }^{7}$

\begin{abstract}
Truth is very closely related to beliefs and facts. Beliefdepends not only on logic but alsosupporting empirical facts. The truth of Sunnatullah (the truth of natural law) is the source of the science truth which always develops. The truth of this science is pragmatic and temporary which means that theprior truth that remains tobe believed can be rejected by the current truth through strong arguments. These truth theories continuously attempt to find out the truth of science. The truth of Dinullah which is truth of the religion of Allah (Islam) leads to the discovery of the nature of truth. This truth only applies to humans as spiritual beings; hence, a truth in the form of "Al-Haq" from God can be believed and rejected by humans.
\end{abstract}

Keywords: truth, science, religion, beliefs, facts, sunnatullah, dinullah.

\section{Introduction}

The problem of truth deals with one's belief of or group's belief. Truth is interpreted as constancy of heart and honesty. If someone believes in something, he considers it to be right or contains truth. According to Bertrand Russell [24]., pragmatically, truth is a relationship between belief and fact(s). These two parts have their respective roles [1], [2], [3], [4], [5].

The argument can be supported by the logic of language. If someone says and believes: "The mango tree in front of my lecture yesterday hit the car," then his sentence is irrational. This irrationality is based on the reality that a mango tree as an immovable planted object is impossible to walk and crash. No one will believe in such expression. Although the sentence is structurally justifiable but it is semantically unacceptable. That is, meaning is very important in sentences [6], [7], [8], [9], [10], [11], [12].

The acceptance to a belief lies in the problem and not the structure. As a matter of proof, it is determined that $5 \times 5=20$. The result of the calculation of multiplication is mathematically wrong. People who believe in the results of these calculations may not have facts. If the facts are traced to the process of events, it will have the truth. For instance, the search is as follows: there are 5 people that each of them carried 5 eggs. The first person carried 5 items, the second person carried 5 items, the third person carried 5 items, the fourth person carried 5 items, and the fifth person carried 5 items. The sum is $5+5+5+5+5=25$. Thus, people who believe that $5 \times 5=20$, the logic is wrong and the belief is incorrect. On the other hand, people who believe that $5 \times 5=25$, the logic can be accepted and the truthis correct. 
In Bahasa Indonesia, kebenaran (truth) is derived from benar (true) or is synonymous with betul (correct). Nonetheless, the word kebetulan (fluke) is semantically different from the word kebenaran (truth). The terminology kebenaran (truth) has inward substance and kebetulan (fluke) is in accordance with outward matters. Those two words (benar and betul) are antonymous with the word salah (wrong). Something that is not benar nor betul (incorrect) means that it is salah (wrong). One believing an incorrect matter has wrong logic.

The difference between a true and logical belief with the false ones can be illustrated as follows. A person who has had hajj (Yahya) and a person who has not been hajj (Jonah). Yahya told about the pleasure of Hajj, so his belief can be correct. However, if the one who told about hajj was Jonah, then his belief could be wrong because he never relied on facts. Jonah only relies on other people's logic and stories. Therefore, to lead to true belief not merely uses logic but there needs to be empirical facts. Empirical facts are facts that can be experienced directly by humans using the five senses.

A mother stated that her milkfish had been stolen by a cat. The mother's statement contains truth but is substantially wrong, because it uses human logic. The question is whether cat can be called a thief or not. The use of the word stealing is always related to religious norms. That is, the act of stealing violates religious norms whereas cats as animals live freely and do not have social and religious norms like humans. Thus, actions that violate social and religious norms for humans cannot be applied to animals. Humans have agreed values [13], [14], [15], [16], [17].

The truth of a statement needs to be supported by facts so that it will lead to true trust. True belief has a significant relationship with facts and truth. Meanwhile, false beliefs have no particular relationship with facts and truth. That people live and die is fact and truth, that people are hungry and full is fact and truth, the sun is fact and truth, Allah Almighty is fact and truth, prayer is fact and truth. Satan is also fact and truth. Therefore, we believe that Satan exists and that belief in the existence of Satan is the truth.

\section{Truth in Science}

The act of asking basically has gotten into the scientific area. The act of asking, answering, and explaining can only be done by intelligent beings. Intellect can be efficacious if it has been supplied by knowledge. A person who has reason is not necessarily knowledgeable, but someone who has knowledge must have reason. Science is a branch of "knowledge." Everything that is known about objects is knowledge. To find out the object, knowledge is required through some predictions or empirical assumptions. Assumptions in science are needed as basis and the cornerstone for the analysis of a knowledge that will eventually find the truth, namely the truth of science. The truth does not have to get into the same conclusion as the assumption has conclusions can be obtained differently from the assumptions. The same conclusions and different assumptions can be determined to have "found the truth".

The case leads to some examples, for instance, a language institution formed a team to conduct research on Javanese dialects in Banyumas and Tegal. Coincidentally, the chair and members of the research all came from Surakarta region which also spoke Javanese of Solo dialect. Researchers have assumed that the Javanese language of Banyumas and Tegal dialects is exactly the same, which is known by the people of Solo with the term "ngapak language". The facts found in the field shows that they were different from the assumptions. The research team found many differences between the Javanese language of Banyumas dialect and Tegal 
dialect. The difference is precisely found in all fields of linguistics such as phonology, morphology, syntax, and semantics. Consider the following example.

a. Saya sudah lapar sekali. (Bahasa Indonesia) (I am very hungry)

Enyong wis kencot banget. (Banyumas)

Enyong wis ngelih nemen.(Tegal)

b. Kamu sekarang sudah tidak dapat menipu lagi. (Bahasa Indonesia) (You cannot tell a lie anymore.)

Kowe saiki wis ora teyeng nglomboni maning. (Banyumas)

Kowen saiki wis belih bisa goroh maning.(Tegal)

c. Kereta apinya tidak sampai-sampai. (Bahasa Indonesia) (The train has not come yet)

Sepure ora gutul-gutul. (Banyumas)

Sepure ora anjog-anjog. (Tegal)

d. The word "bagaimana" ("how" in Bahasa Indonesia) equals to kepriwe (Banyumas) and kepriben or keprimen (Tegal)

e. The word "pulang" (come home) is meant as bali (Banyumas) and balik (Tegal).

Based on observations in the field, the team found that Banyumas people had difficulty communicating with Tegal people. Many vocabularies between the two Javanese languages and the dialect are also very different. The team concluded that the Javanese language of Banyumas dialect turned out to be very different from Tegal Javanese dialect. The results of these research are facts and truths collected from observations in the field. Therefore, truth can be different from the assumptions because reality in the field indicates the existing facts. Thus, the truth will be related to reality [18], [19], [20].

The known facts in science are not facts observed in practice as a whole, but only a partial explanation of observation. Therefore, the truth of science is relative and pragmatic. The truth that is believed in the past can be turned down in the present. It is due to the existence of scientific research or new discoveries that can take down the truth in the past which might be declared wrong in the present. For example, it was believed that the earth was flat but now the truth is rejected as it is now believed that the earth is round. With the argument that the earth is rotating (rotation), only round objects can make a rotation on the axis.

In the area of language, in Bahasa Indonesia the use of words of 'analisa' (for English word analysis) and 'hipotesa' (for English word hypotheses) can be justified in the past but now the correct words are analisis and hipotesis. Another example regarding this case is that people in ancient times made boats only from wood since a theory that is trusted and justified is that water cannot hold objects that has heavier gravity than the density of water. As a result, thetheory stating that objects made of iron can float in water is wrong. Therefore, it was previously believed that only boats from wood could float in water. In fact, now many boats from iron or so-called sea ships roam a vast ocean. Thus, the truth that is believed in the past that only boats that could float in water were taken down after the existence of a ship made of iron. So, to determine the new truth must take down the previous truth to be declared a mistake.

Falsehood and truth are always in contrast. Science is learned not to get a falsehood but to get the truth. However, searching for the falsehood within something based on justified theories is also a process to obtain the truth. All knowledge about something to obtain the truth is included in the category of science. Imam Raghib Al-Ashfahani (in Qardhawi, 1999: 88) states that science is knowing something with its essence. In principle, the nature of science obtains the truth of science. Any learning is substantially planting science upon its wits. The expected results are to obtain "the fruit of knowledge", namely the ability of the truth from the knowledge that is learned. 
It can be exemplified that people who study shamanism or witchcraft are basically looking for the truth of the knowledge, that is, they try to find how to perfectly master the science of shamanism in accordance with their theories. If the shamanic knowledge has been mastered perfectly, it can be stated that they have learned correctly. Otherwise, he always finds mistakes in learning.

If they have mastered the knowledge then challenge people with the knowledge of the shaman does, then what must be blamed is not the mastery of the knowlege yet the misuse of the knowledge itself. It does not mean that learning the knowledge of witchcraft and shamanism is true as the mastery of that knowledge rather causes madlorot (loss) than the benefits. Another example is that mastering the science of karate does not mean that it is wrong. If used to hit innocent people, then it is wrong. A match can also be useful to ignite lights when the electricity goes out but it can also harm the community if it is misused to burn houses. Even a kitchen knife can be used to cut chicken meat (right) but it will be wrong if it is used to stab people. Thus, something is used according to function [21], [22], [23].

Humans are creatures who are required to seek knowledge to supply theirreasoning. Intellect can be useful if it has been filled with knowledge. The nature of human knowledge mentioned in epistemology discusses how knowledge is obtained, by what method is it acquired, and what criteria of truth are expressed. From some of these sections, it is necessary to know the truth criterion of science or often called as the "Theory of Truth". According to Kattsoff (in Kaelan, 1998: 10) the theory of truth has three types: (1) the theory of coherencetruth, (2) the theory of correspondencetruth, and (3) the theory of pragmatic truth. Then, one more according to Lean, namely the theory of the evidence truth.

\section{a. Theory of Coherence Truth}

Coherence is a theory of truth which states that a statement is considered true if the statement is coherent (related) to the previous statement that is considered true. The logical relationship between the present statement and the previous statement is always based on consistent argumentation criteria. If there is consistency in argumentation within a statement, then the statement is true. A fact proves that everything that is dirty, whether it is a place or food, can cause disease. People who are always physically ill will be fragile and easily complain so they can lower gratitude for feeling less comfortable in their lives. Long before modern times, the Prophet had stated that cleanliness was part of faith.

\section{b. Theory of Correspondence Truth}

Correspondence is a theory of truth which states that a statement is considered true if the statement corresponds to the material referred to. Someone stated that the sea water was salty. The statement can be true after conducting verification (testing) to prove that the sea water is indeed salty. A lecturer proudly praised his student "Fulan is very good in English." The statement of the lecturer can be verified through the written or spoken testof English to Si Fulan. If Fulan is able to answer well, then the lecturer's statement is true.

\section{c. Theory of Pragmatic Truth}

Pragmatic is a theory of truth which states that a statement is considered true if its statement has practical benefits for human life. Abadani states that the telephone is very important. As evidence, a father has 12 children and was seriously ill, then the family at home contacted him by telephone to all his children who were out of the city to go home soon. A few hours later, all children can gather to wait for their sick father. Therefore, Abadani's statement is true that telephone is very important because it has practical benefits for human life. 
Television has practical uses for humans, so the statement "television is very necessary for human life to know the political situation" is true.

\section{d. Theory of Evidence Truth}

Evidence is a theory of truth which states that a statement is considered true as contained in the object. For instance, humans are the intelligent creatures and possess an element of rokhani that animals do not have. The statement is true, because the truth is evident (clear and tangible) with the object, that is, the human being as the object of the statement does have reason and rokhani. Therefore, it is very clear and tangible that humans are intelligent; hence, there is no need to verify to prove this statement. The bird flies;kutilang is a bird, so it can fly. The aforementioned statement must be true because its statement is an irrefutable logic of nature which is included in the level of evidential truth. Thus, we directly can know facts and truth as the proof of truth.

The four truth theories discussed in epistemology are the basis for obtaining scientific truth. The truth of science always relies on human logic which always links nature and facts. Indeed the facts known in science are temporary realities and are an explanation of some observations. This is caused by observations of humans who are very limited, imperfect and not absolute. Thus, the reality that we hold is basically a mere hypothesis until humans discover new realities to strengthen the truth of their knowledge to a certain level. Sullivan in (Khan, 1982: 41-42) argues "The agreement on scientific theories stipulates that the notion of a valid scientific theory is a working hypothesis that is fully successful, but it still allows the whole theory to fall out. Therefore, the theories that we are currently looking at are nothing but an analogy based on our limited means of observation. And the problem of reality (facts) in the world of science is still a pragmatic problem". Thus, it can be concluded that the truth of science is pragmatic until it discovers new facts to be considered as truth and so on. It is because human problems and their knowledge will be destroyed at the same time with the destruction of this universe which is called as the "doomsday".

\section{Religion Truth}

Truth is always related to "matter of trust." If we believe something, then something is considered true. In science, to change the right to be sure needs a proof. Science is basically the path to understand, which is sure. Someone who understands correctly within his heart, both about truth and error, is basically sure. People who believe means that they have no doubts (doubtful) and are also not prejudiced (dzan). So, belief is a loss of doubt and prejudice. We are convinced of the error of Darwin's theory and we are convinced of the truth of the Koran that Adam was the first man. We also believe that Satan is a creature who always denies and tempts humans, and angels are creatures who are always obedient to Allah SWT. The reach of human science cannot enter the supernatural realm of demons and angels. However, we believe that both creatures exist and are the truth of religion (Islam). The truth of religion gets into the conscience and is processed by the power of reasoning, that is, emergence of a belief is called as "faith". Therefore, the truth of religion relies on faith.

To achieve belief in the truth of religion, the matter of belief, which is in the Qur'an according to Qardhawi (1999: 145), can be classified into three types (1) 'ilmul-yaqin, (2) 'ainul-yaqin, and (3) haqqul-yaqin. The steps of belief can be exemplified: Someone tells you that he has a mango that tastes very sweet, you are not doubtful about the person's story ('ilmul- 
yaqin). Afterward, the person shows his mangoes and you are sure ('ainul-yaqin). Next, the person lets you eat it and it turns out it is really sweet. (haqqul-yaqin).

Ibnul Qayyim (in Qardhawi, 1999: 147) says that our knowledge of heaven and hell is classified as 'ilmul-yaqin'. That the heaven is shown in time to the people "muttaqin" and witnessed by all beings, and that the hell is shown to the ungodly and witnessed by all beings are classified to 'ainul-yaqin '. If the heaven people are put into it, and the hellish peopleare put into hell, then that is 'haqqul-yaqin'. The belief that God exists and is single is haqqul-yaqin. The main key to belief in the truth of religion is faith, while science is a supporter of the belief in the truth of the religion of God Almighty.

According to human logic, the truth is single. If there are two things considered to have the truth, one of them is a mistake. Therefore, if there are two contradictory things then (1) it is not possible to both be true, (2) it is impossible that both of them are wrong, (3) the correct one of them. Humans cannot achieve perfect truth because of their limitations. Humans only come to the truth in part of that single truth. The truth comes from God Almighty. According to AlBaqarah's letter 147, it states that "Truth is from your Lord". The truth according to the Koran is called "Al-Haq". Everything that comes from God is al-haq (truth). When humans get the truth basically comes from God, on the contrary if it gets falsehood, it means it denies the truth of God. In the Qur'an the truth is divided into two kinds, namely the Sunnatullah Truth and Dinullah's Truth [28]. These two truths are not theories of truth but the nature of truth.

a. Sunnatullah Truth

The sun, earth, moon, and planets in the universe are circulating according to natural law. Likewise, the human realm as a physical being will always follow natural law. Human blood is red, that is, it dies if it runs out of blood. Every object thrown anywhere will surely fall to earth. Everyone must believe and justify such natural law. People of any religion must believe and justify that rice will not grow in a desert without water. On the other word, natural law is a truth that can be recognized by humans from any group and religion. The truth is called the Truth of Sunnatullah or the law of nature. In other words, the truth of Sunnatullah will be trusted and recognized by all humanity, both humans who are classified as unbelievers and those who believe.

Human body is only a vehicle for rokhani. The human body will return to be buried under the land and the rokhani will face the God. Humans as physical beings will follow the sunnatullah and as a rokhani creature will apply the law of Allah, namely the law of religion of Allah.

b. Dinullah Truth

We are sure that the religion that God supplies is Islam. For those who believe in the truth of the religion of Islam, there is no doubt for them. In contrast, for the unbelievers, the truth of Islam is only a hoax and nonsense. They do not only hesitate but aresure that Islam was wrong. In the reality of human life, there are only two groups: those who are grateful and those who are kufr. Humans as rokhani beings will follow God's religious law. The truth of God's religious law (Islam) is called the Truth of the Holy Prophet. God's religious law will regulate human attitude and behavior because human behavior comes from its rokhani. In order to create harmony and order in life, the rokhani needs to be guided, admonished, and poured with akhlakul karimah and Nur Illahiyah teachings.

Humans as physical beings always follow the law of sunnatullah and all acknowledge the truth. As a rokhani creature, he follows the law of Allah, but there are those who believe and some who deny the truth. As stated in the Qur'an, Surat An-Insan, verse 3 "Indeed we have shown them the right path but there are those who are grateful and some who are kufr". The truth of God's religious law (dinullah) has the difference in its acceptance as there are those who 
refuse and some who are convinced. Why are there people who pray and do not pray? Why are there people who believe and some who do not believe that Muhammad was the Messenger of Allah? For Muslims, prayer and thebelief on Muhammad as Rasulullah are the truth. Conversely, it is a lie and mistake for others. For Christians, Isa is Jesus and is believed as God. However, for the Muslims, Isa is a Prophet.

The question that arises is which is the truth among such differences of beliefs? If you are a Muslim, you will certainly believe the truth about prayer, Muhammad is an Apostle, and Jesus is only a prophet not God. However, a Christian certainly will not believe the truth about prayer, Muhammad as an Apostle, and he believes that Jesus is God. Therefore, the truth of Allah must be based on faith and no verification is needed, likewise believing in the truth of science. When the Prophet Muhammad preached continuously to deliver the truths of Islam, the infidels were even more determined to oppose him. Next, the letter Al-Kaafiruun verse 6 came down: "for you your religion, and for me my religion".

People who do not believe in God are includedto be atheists and those who believe that God is one are called as monotheists. Islam is a monotheistic religion, which only has one God that is Allah. In the truth of Allah, it is not easy to convince people of different religions - even to convince an atheist. Below is illustration of the truth of dinullah in the debate about God's Existence between Islamic Youth (IY) and Atheist Youth (AY).

\begin{tabular}{|l|l|}
\hline IY & Do you believe the existence of God? \\
AY & No, I don't. Why do you believe in God as he does not exist. \\
IY & Yes, because God is fact and truth \\
AY & Where is the fact? \\
IY & I, you, and all humans are His creatures. \\
AY & It is a lie. Humans are created by themselves through their fathers and mothers. \\
IY & Like the Sun and the Earth. Are they created by themselves? \\
AY & Yes, that is right. All is through the natural process. \\
IY & Then, who processes it naturally? \\
AY & Yes. The nature it self. \\
IY & Okay. Do you believe in the death of human? \\
AY & Yes, I do as I frequently saw the dead people. \\
IY & Then, where do they go after the death? \\
AY & Yes, they just go. \\
IY & So you do not believe in the occurrence of doomsday and the day of judgment. \\
AY & God does not exist, so does the doomsday or the day of judgment. \\
& $\begin{array}{l}\text { Therefore, I am fortunate and you are unfortunate. Why am I unfortunate and are } \\
\text { IY }\end{array}$ \\
AY & Let's be logical. If my belief is true that God exists then I get a good reply and enter \\
& the heaven because I have obeyed His command. Meanwhile, you will get a bad \\
IY & $\begin{array}{l}\text { reply, tortured by Allah Almighy, and be put into hell. You understand my best } \\
\text { friend, didn't you? }\end{array}$ \\
AY & Okay. Second logic. If your belief is true that God does not exist, I will remain \\
& lucky and I will not be tortured because there is no day of judgment. Likewise, \\
& heaven and hell do not exist. So, whether or notthe God exists, I am still lucky and \\
IY & you are the one who loses. \\
& thinking for a while). Oh yes, you are then logic and rational, buddy. \\
&
\end{tabular}




\begin{tabular}{|l|l|}
\hline AY & $\begin{array}{l}\text { Indeed. The truth of Islam is logic and rational. Islam is a religion of logic- no } \\
\text { religion for those without logic. That is the message of my Prophet, Muhammad }\end{array}$ \\
& Rasullah saw, a true teacher. \\
& $\begin{array}{l}\text { Am I too late to be in your religion? } \\
\text { Not yet, it is never too late in Islam. Alhamdulillah. }\end{array}$
\end{tabular}

\section{Conclusion}

The truth of the natural law 'Sunnatullah Truth' used as the source of the truth in science requires empirical evidence and verification for proof. Meanwhile, the truth of the religion of God 'Dinullah Truth' is always based on faith and the true nature of truth. People who are not believers or unbelievers certainly cannot find the true nature of this truth.

The truth of the science and truth of religion is always compatible and not contradictory. Islam is the religion of reason, so Muslims are required to seek knowledge with their logic and reasoning. If there is a conflict or difference, the possibility of the knowledge is not correct, or the understanding of the verse is not correct.

\section{References}

[1] L. Hogg, "Funds of Knowledge: An Investigation of Coherence Within the Literature," Teach. Teach. Educ., vol. 27, no. 3, pp. 666-677, 2011.

[2] F. Raia, "Learning, Culture and Social Interaction Identity, tools and existential spaces," Learn. Cult. Soc. Interact., no. April, pp. 0-1, 2018.

[3] C. Levisen, "The social and sonic semantics of reggae : Language ideology and emergent socialities in postcolonial Vanuatu," Lang. Commun., pp. 1-15, 2016.

[4] B. A. Rumsey, "The sociocultural dynamics of indigenous multilingualism in northwestern Australia," Lang. Commun., pp. 1-11, 2018.

[5] J. Potters, "Heuristics versus norms : On the relativistic responses to the Kaufmann experiments," Stud. Hist. Philos. Mod. Phys., vol. 66, pp. 69-89, 2019.

[6] N. Riemer, "Language \& Communication Cognitive linguistics and the public mind : Idealist doctrines , materialist histories," Lang. Sci., vol. 64, pp. 38-52, 2019.

[7] R. J. Leblanc, "Language \& Communication Pedagogic ventriloquation : Projected constructed direct reported speech in teacher talk," Lang. Sci., vol. 64, pp. 25-37, 2019.

[8] Y. Guo, S. B. Piasta, L. M. Justice, and J. N. Kaderavek, "Relations among Preschool Teachers Self-efficacy, Classroom Quality , and Children's Language and Literacy Gains," Teach. Teach. Educ., vol. 26, no. 4, pp. 1094-1103, 2010.

[9] M. Souto-manning, "On Children as Syncretic Natives : Disrupting and Moving Beyond Normative Binaries," J. Early Child. Lit., vol. 13, no. 3, pp. 371-394, 2012.

[10] P. D. Ware and M. Warschauer, "Hybrid Literacy Texts and Practices in TechnologyIntensive Environments," Int. J. Educ. Res., vol. 43, pp. 432-445, 2005.

[11] P. C. Hogan, "A Different Postcolonialism: the Cultural Ethics of Yasujiro Ozu's Late Spring Patrick Colm Hogan," Image Narrat., vol. 11, no. 2, pp. 18-37, 2010.

[12] J. Rosaler and R. Harlander, "Naturalness, Wilsonian renormalization , and " 
fundamental parameters' in quantum fi eld theory," Stud. Hist. Philos. Mod. Phys., no. Xxxx, pp. 1-17, 2019.

[13] S. Abu-rabia-queder and S. Abu-rabia-queder, "The Activism of Bedouin Women : Social and Political Resistance," Stud. Cult. Polity Identities, vol. 7, no. 2, pp. 67-84, 2007.

[14] A. De Vido, "Reclaiming the Streets : Investigating Female Experience of Cinematic Urban Violence Reclaiming the Streets : Investigating Female Experience of Cinematic Urban Violence," J. Fem. Sch., vol. 15, no. 15, pp. 18-36, 2018.

[15] T. Roeder, "“ You Have to Confess ': Rape and the Politics of Storytelling," J. Fem. Sch., vol. 9, no. 9, pp. 18-29, 2018.

[16] F. J. Boge, "The best of many worlds, or , is quantum decoherence the manifestation of a disposition ?," Stud. Hist. Philos. Mod. Phys., no. xxxx, pp. 1-10, 2019.

[17] J. Birch, "Inclusive fitness as a criterion for improvement Jonathan," Stud. Hist. Philos. Biol Biomed Sci, no. September 2018, 2019.

[18] B. Smith, "Turning Language Socialization Ontological: Material Things and The Semiotics of Scaling Time in Peruvian Aymara Boyhood," Lang. Commun., vol. 46, pp. 42-50, 2016.

[19] M. Davis and M. Davis, "Approaching conversational humour culturally : A survey of the emerging area of investigation," Lang. Commun., pp. 1-9, 2017.

[20] C. Ariel and O. Iris, "No communication without manipulation : A causal-de fl ationary view of information," Stud. Hist. Philos. Sci., vol. 73, pp. 34-43, 2019.

[21] J. Steinerov, "Information Literacy Studies and Human Information Behaviour," Inf. Lit. Stud. HIB, vol. 2, pp. 53-69, 2016.

[22] J. Turner, "Academic literacies: Providing a Space for the Socio-Political Dynamics of EAP,” J. English Acad. Purp., vol. 11, no. 1, pp. 17-25, 2012.

[23] E. Ding, "Metaphor and Culture," Asian Soc. Sci., vol. 5, no. 1, pp. 47-69, 2009. 